POLLACK PERIODICA

An International Journal for Engineering and Information Sciences

DOI: $10.1556 / 606.2019 .14 .1 .8$

Vol. 14, No. 1, pp. 75-84 (2019)

www.akademiai.com

\title{
EXPERIMENTAL VERIFICATION OF REAL BEHAVIOR OF BRIDGE STRUCTURES USING PROOF-LOAD TESTS
}

\author{
${ }^{1}$ Martin VAVRUŠ, ${ }^{2}$ Ján BUJŇÁK, ${ }^{3}$ Peter KOTEŠ ${ }^{*}$ \\ ${ }^{1,2,3}$ Department of Structures and Bridges, Faculty of Civil Engineering, University of Žilina \\ Univerzitná 8215/1, 01026 Žilina, Slovakia, \\ e-mail: ${ }^{1}$ martin.vavrus@fstav.uniza.sk, ${ }^{2}$ jan.bujnak@fstav.uniza.sk, ${ }^{3}$ kotes@fstav.uniza.sk
}

Received 28 December 2017; accepted 18 June 2018

\begin{abstract}
The aim of the paper is to point out the inevitability of the proof-load tests for the real and correct behavior of bridge structures in ultimate limit state and maximum allowable deformations in serviceability limit states. It is needed to point to the most consequences of resistance, reliability, durability and lifetime of the bridge structures. Using the proof-load tests for new bridges is prescribed by the Slovak standard STN 736209.
\end{abstract}

Keywords: Bridge, Proof-load test, Real behavior, Truck, Deflection, Verification

\section{Introduction}

Bridges are inseparable and significant elements of the communication systems and thus of the entire traffic infrastructure. In the past, they have been and still are considered to be the most important and significant construction works in the hierarchy of engineering structures [1]. By building up and putting the bridge into operation, the care about the bridge object does not end. Bridge administrator should perform the maintenance of the structure and, in addition, the supervision program. This means that he should perform regular inspections, detect possible defects and analyze their influence on reliability.

In general, the deficiencies of the bridge structure, from its creation (start of design and construction) to the end of the lifetime, are divided into two basic groups [2]:

${ }^{*}$ Corresponding Author 
- defects of the bridge object or its part before putting into operation - production defects;

- defects of the bridge object or its part after putting into operation - failures.

The production defects characterize the difference between the properties required for the new structure and the actual structure properties just after the completion. The defect does not always mean reducing the resistance, durability or usability of the structure or its element. Essentially, they are hidden design defects that are caused by inappropriate design or realization, so that they arise in the design and during construction of the bridge [3]-[4]. They should be revealed using reception of main inspections and control proof-load tests. If they are found, they are the so-called 'visible' defects, which should be removed before starting of operation. If they do not influence the load-carrying capacity and the reliability [5], they can be removed gradually even during operation. However, there can be the so-called 'hidden' defects that were not found out for any reason. These are very dangerous because they can be the source of later faults.

Defects may occur:

- during the design phase, because of

- incorrect conception [6];

- incorrect construction solution;

- incorrectly designed details; and

- bad designer information about the real properties of the materials [7];

- during the construction, because of

- concrete quality (concrete composition - recipe, transport - transport concrete, fresh concrete working-up, concreting and compaction, treatment);

- reinforcement (lower quality, depositing reinforcement, concrete cover layer);

- geometric dimensions (element dimensions, flatness, inclination, dimensioning or prefabrication position);

- surface protection of concrete (painting, coats, coatings, insulation);

- during the operation due to

- $\quad$ aging of materials and structures [8]-[9];

- extraordinary loads [10]-[13];

- aggressiveness of the environment[14]-[15];

- inadequate or inappropriate maintenance.

As it has been mentioned above, proof-load tests have to be carried out to detect defects prior to putting the bridge into operation [16]-[19]. Basically, it is an experimental verification of the real behavior of a bridge structure in order to detect the visible and hidden defects that could limit or disable the operation of the bridge. The proof-load tests must be carried out according to Slovak standard STN 736209 [20]. 


\section{Proof-load test of bridges}

Standard STN 736209 [20] determines the design, safety and processing of the load test in Slovakia, which is necessary for putting the bridge structure into operation. During the loading, a set of measurements is performed. Depending on the character of the test load, the proof-load tests are divided into static and dynamic. The static load tests are divided into basic, stricter and extraordinary. The static test load has negligible dynamic effects on the structure. It must accurately represent the real load of the bridge and move easily to allow a rapid change of load to complete unloading. Measuring devices are installed on the bridge, and sensors and long-term-monitoring devices are also used (if installed). Usually, the following measurements are normally performed:

- deformations/deflections of the superstructure;

- settlement and tilting of the abutments and piers;

- shifts and slew of the superstructure and substructure;

- width of the cracks.

Efficiency of the test load $\eta$ is determined from the values of the vertical deformations in the mid-span, as well as from the bending moment values at those same points according to STN 736209 [20]. The numerical values of those test load efficiencies, for the most stressed sections in the mid-span of each field, should fulfil the following conditions:

$$
\begin{aligned}
& \eta=\frac{f_{\text {test }}}{f_{\text {cal }}}, \\
& \eta_{M}=\frac{M_{\text {test }}}{M_{\text {cal }}}, \\
& 0.5<\eta \leq 1.0, \\
& 0.8<\eta_{M}<1.0,
\end{aligned}
$$

where $f_{\text {test }}$ is the vertical deformation in the mid-span measured during proof-load test; $f_{c a l}$ is the vertical deformation in the mid-span calculated from the theoretical model; $M_{\text {test }}$ is the bending moment in the mid-span measured during proof-load test; $M_{\text {cal }}$ is the bending moment in the mid-span calculated from the theoretical model.

In construction design theory, the design is reliable if its design resistance $(R)$ and design load effect $(E)$ fulfil the inequality

$$
R>E \text {. }
$$




\section{Verifying real behavior of bridge structures using proof-load tests}

In this paper two new bridge objects are presented, where the proof-load tests were performed, therefore, their real behavior was verified before putting them into operation.

\subsection{Object No. 1 - bridge over Old Creek on road I/59 near Dolný Kubin}

The first bridge structure by-passes the natural valleys with a creek named Old Creek and afforested with mixed vegetation. The bridge conducts the road I/59 in $\mathrm{km}$ 1.821 with a three-lane pavement arrangement of category $\mathrm{C} 11.5 / 70$ with width of $14.75 \mathrm{~m}$ between barrier railings on the left-hand side of the bridge with the slow-speed lane. The communication on bridge is along a curve with radius $190 \mathrm{~m}$ with a consequential transition curve. The vertical declination is $6 \%$. The pavement has a onesided transverse declination also of $6 \%$. The superstructure, consisting of three beams of $2.4 \mathrm{~m}$ in height and $217.5 \mathrm{~m}$ in length, was made of the pre-stressed concrete and has 6 spans. The theoretical spans of continuous girders are $28.0 \mathrm{~m}+4 \mathrm{x} 40.0 \mathrm{~m}+28.0 \mathrm{~m}$ in the communication axis (see Fig. 1). The beams of constant height of $2.4 \mathrm{~m}$ have a width at the bottom edge of $1.0 \mathrm{~m}$ and $1.2 \mathrm{~m}$ at the upper edge. The total width of the bridge deck is $17.25 \mathrm{~m}$. The base thickness of the slab (bridge deck) is $250 \mathrm{~mm}$ and it is increased to $400 \mathrm{~mm}$ when connected to the beams - using haunches. At the end of the cantilever, the slab was of a size $200 \mathrm{~mm}$. The bridge was made of concrete C35/45 XC4, XD3, XF4, XA3 (SK) - Cl 0.1 - S3 and cast in-situ on a truss formwork. The cables from 19 strands $\phi$ Ls $15.7 / 1860 \mathrm{MN} / \mathrm{m}^{2}$ in tubes $\phi 95 \mathrm{~mm}$ pre-stressed at $1440 \mathrm{MN} / \mathrm{m}^{2}$ in sequential stages were used for pre-stressing. The superstructure was supported on elastomeric bearings.

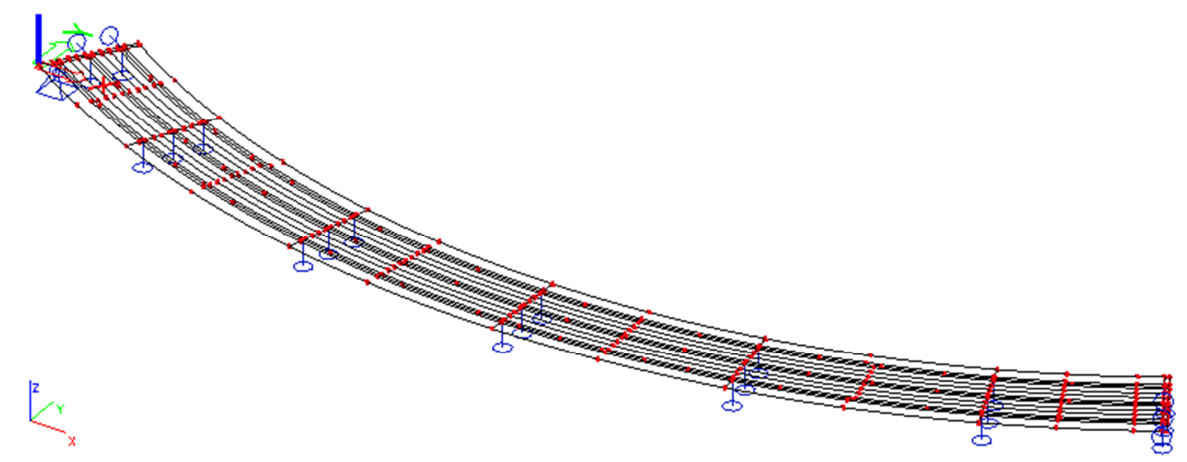

Fig. 1. Slab-girder model of bridge structure No. 1

First numerical model

A slab-girder model developed in SCIA Engineer was used for a model of the bridge structure. The slab of bridge deck was modeled as slab elements. The three longitudinal main beams and cross beams were modeled as $2.4 \mathrm{~m}$ high ribs of slab with inclined 
haunches in the transverse direction, the effective width of the beams/ribs was specified as unsymmetrical. Due to verification, it was not needed to model the pre-stressed cables due to low influence on a vertical deflection.

\section{Second numerical model - simplified model for comparison}

For verification and comparison of numerical results and results from measurements, there was developed second model. For simplifying, the simple girder bridge model was used as second model. The model was loaded by stand-alone forces on eccentricity. Position and effectiveness of variable load (LM1) was verified on slabsgirder model. The proof-load test TATRA 815 was modeled in the same position as in real structure. The vertical displacement in middle span were observed, which was compared with a vertical deflection from slabs-girder model and the proof-load test. Subsequently, individual deformations were compared.

\section{Variable load according to standard}

The load model LM1 according to code STN EN 1991-2 [21] was applied for each field in that bridge structure. A maximum Uniformly Distributed Load (UDL) of $\alpha_{q 1} \cdot q_{1 k}=8.10 \mathrm{kN} / \mathrm{m}^{2}$ and a Tandem System (TS) was located in the edge lane in the case of the second span, in the case of first and third span, the maximum UDL and TS (axle forces) were located in the pavement axis. The TS was arranged for the maximum bending moment and maximum deflections in the center of each span. Three loading states were performed in the first three spans.

\section{Test load for proof-load test}

TATRA 815 trucks were used for test load. The front axle transmits a force of $64.4 \mathrm{kN}$ and a back axles transmit forces $2 \times 107.8 \mathrm{kN}$. The load was modeled as a uniformly distributed load over the area $0.4 \times 0.4 \mathrm{~m}$ under each wheel according to STN EN 1991-2 [21].

\section{Organization and processing of the proof-load test}

The static test was performed in that manner to achieve the greatest effect in the middle of each span of the continuous superstructure. The vertical deflections of the beams in the middle of each span, as well as decreases of the lower edges of the beams at the positions of bearing over the supports, were measured. A settlement of all supports (abutments and piers) was measured geodetically. The vehicles were arranged at the specified places. Once the measured deflections have stabilized, the final deformations have been recorded, after that the test load has left the bridge structure and deformations have been red again. The procedure was used also for testing of other two bridge spans. 


\section{Results of measurement}

During the test, the bridge structure, bearings and bridge supports were monitored. No anomalies were found in the behavior of the bridge structure under test load. During the test, cracks or opening of the working or dilatation joints were not found. The results of proof-load test of bridge No. 1 are shown in Table $I$.

\section{Table I}

Comparison of theoretical and measured values - bridge No. 1

\begin{tabular}{|c|c|c|c|c|c|c|}
\hline Span & Beam & $\begin{array}{l}\text { Deflection } \\
\text { due to the } \\
\text { test load } \\
\text { (slab-girder } \\
\text { model) } \\
\mathrm{f}_{\text {calc, } 1[\mathrm{~mm}]}\end{array}$ & $\begin{array}{c}\text { Deflection } \\
\text { due to the } \\
\text { test load } \\
\text { (simple } \\
\text { girder } \\
\text { model) } \\
\mathrm{f}_{\text {calc }, 2[\mathrm{~mm}]}\end{array}$ & $\begin{array}{l}\text { Measured } \\
\text { values of } \\
\text { deflection } \\
{[\mathrm{mm}] \mathrm{f}_{\text {test }}}\end{array}$ & $\begin{array}{c}\text { Efficiency } \\
\text { of the test } \\
\text { load } \\
\eta=\mathrm{f}_{\text {test }} / \mathrm{f}_{\text {calc, }, 1} \\
{[-]}\end{array}$ & $\begin{array}{c}\text { Efficiency } \\
\text { of the test } \\
\text { load } \\
\eta=f_{\text {test }} / f_{\text {calc }, 2} \\
\quad[-]\end{array}$ \\
\hline \multirow{3}{*}{$\begin{array}{l}\text { Span } \\
1\end{array}$} & 1 - outer & 2.83 & 3.90 & 2.400 & 0.784 & 0.615 \\
\hline & 2 - middle & 4.22 & 3.00 & 3.680 & 0.888 & 1.226 \\
\hline & 3- internal & 2.41 & 2.20 & 2.320 & 0.886 & 1.054 \\
\hline \multirow{3}{*}{$\begin{array}{l}\text { Span } \\
2\end{array}$} & 1 - outer & 12.90 & 18.30 & 11.745 & 0.950 & 0.641 \\
\hline & 2 - middle & 8.19 & 7.90 & 8.090 & 0.994 & 1.024 \\
\hline & 3-internal & 2.53 & 2.60 & 2.035 & 0.639 & 0.782 \\
\hline \multirow{3}{*}{$\begin{array}{l}\text { Span } \\
3\end{array}$} & 1 - outer & 7.12 & 9.40 & 6.080 & 0.808 & 0.646 \\
\hline & 2 - middle & 9.70 & 7.30 & 8.995 & 0.927 & 1.232 \\
\hline & 3- internal & 5.73 & 5.30 & 5.000 & 0.897 & 0.943 \\
\hline
\end{tabular}

\subsection{Object No. 2 - bridge over highway D1 on road III/018165}

The second bridge structure by-passes the road III/018165 over the highway D1 in $\mathrm{km}$ 7.290. In addition, in this case the communication on the bridge is along a curve with radius $175 \mathrm{~m}$ with a consequential transition curve.

The vertical declination is changed from $5 \%$ to $1.21 \%$. The pavement has again onesided transverse declination of $6 \%$ with decreasing to the left-hand side. Its width of $8.20 \mathrm{~m}$ is bounded on the left by a path with width $0.75 \mathrm{~m}$. On the right-hand side of the pavement, there is a cornice (fascia girders) with a vehicle parapet. The superstructure of the bridge is four spans continuous slab structure with theoretical spans $21.0+$ $2 \times 27.0+21.0$ m made from concrete C 30/37-XC4, XD1, XF2 (SK) -Cl 0.1.

The middle trapezoidal cross section has a structural height of $1.40 \mathrm{~m}$ and a width at the bottom edge of $2.50 \mathrm{~m}$, which gradually increases to a height of $4.20 \mathrm{~m}$ with inclined haunches up to $0.8 \mathrm{~m}$. In addition, the consoles that are fixed into this basic cross-section pass into a total width of $9.58 \mathrm{~m}$ on the upper surface of slab. The superstructure was pre-stressed with 12 cables composed of 18 stabilized strands $\varnothing$ Ls $15.7 / 1860 \mathrm{MN} / \mathrm{m}^{2}$. 


\section{First numerical model}

For modeling the bridge structure, the slab-girder model was again used in SCIA Engineer. The main supporting element of the model is the slab with variable thickness using haunches. At the center of the structure, the thickness of the slab is $1400 \mathrm{~mm}$ of width of $2.5 \mathrm{~m}$, and another slab with a thickness of $1000 \mathrm{~mm}$ and of width of $0.850 \mathrm{~m}$ is joined to it. It is finished with a $425 \mathrm{~mm}$ thick slab. There is a $975 \mathrm{~mm}$ monolithic cross-section of the transverse girder above the support.

\section{Second numerical model - simplified model for comparison}

As in the previous object, there was developed simple girder model. Cross-section is a similar to real cross-section. Model is loaded with forces arranged according to loading scheme. The pre-stressed cables were not again modeled due to low influence on vertical deflections. The results from both models and real measurements were again compared (Fig. 2).

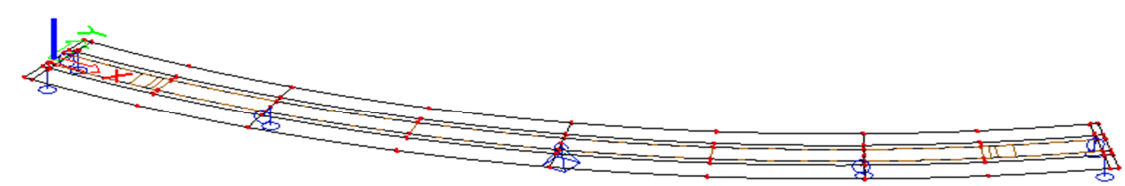

Fig. 2. Slab-girder model of bridge structure No. 2

\section{Variable load according to standard}

Since the bridge was designed according to the old Slovak standards valid before 2010 (STN 736206 [22]), the variable load was considered according to STN 736203 [23]:

- ZZI load: the forces of tandem system were modeled as a uniformly distributed load of $1000 \mathrm{kN} / \mathrm{m}^{2}$ on area of the wheel in two load lanes and the remaining part was modeled as a continuous uniformly distributed load of $2.50 \mathrm{kN} / \mathrm{m}^{2}$. The set of loads were placed on the structure to determine the maximum values of the shear forces and bending moments, as well as the deflections in the spans and over the supports;

- ZZII load: the UDL of $9.00 \mathrm{kN} / \mathrm{m}^{2}$ on the lane of width of $3.0 \mathrm{~m}$ and next UDL of $3.50 \mathrm{kN} / \mathrm{m}^{2}$ at the remaining lanes;

- 4-axle vehicle: the axles of the vehicle were modeled as a uniformly distributed load of $833.33 \mathrm{kN} / \mathrm{m}^{2}$ on area of wheels. The axles are located in the edge lane;

- Specific load: the axle forces were modeled as a uniformly distributed load of $437.50 \mathrm{kN} / \mathrm{m}^{2}$ over areas of the wheels. 


\section{Test load for proof-load test}

In the model, the trucks TATRA 815 were modeled as forces of $2 \times 55.0 \mathrm{kN}$ for the front axle and $2 \times 30.0 \mathrm{kN}$ for the back axles. The positions of trucks were placed in the most effective position to detect the maximum bending moments, shear forces and deformations.

The static test was carried out in the same way as previous bridge. The resistance sensors TR 50 were used for measurement of the beam deflections in the center of the spans and the pushing of the bearings.

\section{Results of measurement}

During the test, again the bridge structure, bearings and bridge supports were monitored. Moreover, again no anomalies were found in the behavior of the bridge structure under test load. No cracks in the superstructure were identified during the test. The achieved results of proof-load test of bridge No. 2 are shown in Table II.

Table II

Comparison of theoretical and measured values - bridge No. 2

\begin{tabular}{|c|c|c|c|c|c|c|c|}
\hline Span & $\begin{array}{l}\text { The } \\
\text { edge of } \\
\text { slab }\end{array}$ & Test load & $\begin{array}{c}\text { Deflection } \\
\text { due to the } \\
\text { test load } \\
\text { (slab- } \\
\text { girder } \\
\text { model) } \\
\mathrm{f}_{\text {calc, },} \\
\text { [mm] }\end{array}$ & $\begin{array}{c}\text { Deflection } \\
\text { due to the } \\
\text { test load } \\
\text { (simple } \\
\text { girder } \\
\text { model) } \\
\mathrm{f}_{\text {calc, } 2[\mathrm{~mm}]}\end{array}$ & $\begin{array}{c}\text { Measur } \\
\text { ed } \\
\text { values } \\
\text { of } \\
\text { deflecti } \\
\text { on } \\
\mathrm{f}_{\text {test }} \\
{[\mathrm{mm}]}\end{array}$ & $\begin{array}{c}\text { Efficienc } \\
\mathrm{y} \text { of the } \\
\text { test load } \\
\eta=\mathrm{f}_{\text {test }} / \mathrm{f}_{\text {cal }} \\
\mathrm{c}, 1[-]\end{array}$ & $\begin{array}{c}\text { Efficien } \\
\text { cy of } \\
\text { the test } \\
\text { load } \\
\eta=f_{\text {test }} / f_{c} \\
\text { alc, } 2[-]\end{array}$ \\
\hline $\begin{array}{l}\text { Span } \\
1\end{array}$ & $\begin{array}{l}\text { outer } \\
\text { internal }\end{array}$ & $\begin{array}{c}6 \mathrm{x} \\
\text { TATRA } \\
815\end{array}$ & $\begin{array}{l}6.46 \\
5.24\end{array}$ & $\begin{array}{l}4.40 \\
3.30\end{array}$ & $\begin{array}{l}5.765 \\
5.385\end{array}$ & $\begin{array}{l}0.905 \\
0.796\end{array}$ & $\begin{array}{l}1.310 \\
1.631\end{array}$ \\
\hline $\begin{array}{l}\text { Span } \\
2\end{array}$ & $\begin{array}{l}\text { outer } \\
\text { internal }\end{array}$ & $\begin{array}{c}6 \mathrm{x} \\
\text { TATRA } \\
815\end{array}$ & $\begin{array}{c}10.51 \\
9.34\end{array}$ & $\begin{array}{l}6.70 \\
6.20\end{array}$ & $\begin{array}{l}9.880 \\
8.850\end{array}$ & $\begin{array}{l}0.808 \\
0.817\end{array}$ & $\begin{array}{l}1.474 \\
1.427\end{array}$ \\
\hline $\begin{array}{l}\text { Span } \\
3\end{array}$ & $\begin{array}{l}\text { outer } \\
\text { internal }\end{array}$ & $\begin{array}{c}6 \mathrm{x} \\
\text { TATRA } \\
815\end{array}$ & $\begin{array}{c}8.85 \\
10.53\end{array}$ & $\begin{array}{l}5.10 \\
7.00\end{array}$ & $\begin{array}{l}7.930 \\
9.985\end{array}$ & $\begin{array}{l}0.681 \\
0.920\end{array}$ & $\begin{array}{l}1.554 \\
1.426\end{array}$ \\
\hline $\begin{array}{l}\text { Span } \\
4\end{array}$ & $\begin{array}{l}\text { outer } \\
\text { internal }\end{array}$ & $\begin{array}{c}6 \mathrm{x} \\
\text { TATRA } \\
815 \\
\end{array}$ & $\begin{array}{l}5.38 \\
5.77\end{array}$ & $\begin{array}{l}3.20 \\
3.70\end{array}$ & $\begin{array}{l}4.490 \\
5.790\end{array}$ & $\begin{array}{l}0.754 \\
0.877\end{array}$ & $\begin{array}{l}1.403 \\
1.564\end{array}$ \\
\hline
\end{tabular}

\section{Conclusions}

Obtained results show that the computer models results are not much different from the real state. When the proof-load tests were correctly performed, the values were identical to the values from model (program). Thus, the bridge structures are reliable and are designed and usable for the operation throughout its planned lifetime. This means that the bridge objects were reliable and can be put into operation. 
This paper compares two different methods of modeling. In the first model, which is modeled as slab-girder model, results are more precisely and approaching real results from the proof-load test. In the second models are not results so satisfactory. From time viewpoint, the simply-girder model is preferable, but from safety, it is better to use a slab-girder model. For practice, it is important that simply girder models are more conservative than slab-girder models, what is on the safe side but is lower effectiveness.

The bridge structures have been designed and built to perform the function of safely transmitting all components of permanent and variable loads over the lifetime. For comparison and verification of response and maximum load, the proof-load tests serve to detect all errors before putting bridge into operation. The task of proof-load tests is to verify the real behavior of bridges for safe putting into operation. From that follows the requirement that the bridge objects have to fulfill certain parameters that, in their complexity, reflect their serviceability and service lifetime.

\section{Acknowledgements}

The research is supported by the Slovak Research and Development Agency under contract No. APVV-14-0772, and by Research Project No. 1/0413/18 and No. 012ŽU4/2016 of the Slovak Grant Agency and also by the project DS-2016-0039 in frame of bilateral cooperation.

\section{References}

[1] Koteš P., Vičan J. Recommended reliability levels for the evaluation of existing bridges according to Eurocodes, Structural Engineering International, Vol. 23, No. 4, 2013, pp. 411-417.

[2] Tomica V., Sokolík A., Zemko Š. Maintenance and reconstruction of bridges, (in Slovak) Alfa, Bratislava, 1992.

[3] Bilč́́k J., Dohnálek J. Reconstruction of concrete structures, (in Slovak) Jaga, 2003.

[4] Vlček M., Moudrý I., Novotný M., Beneš P., Maceková V. Disorders and reconstruction of buildings, (in Czech) ERA group, Brno, 2006.

[5] Benko V. Reliability of structures (according to Eurocodes), (in Slovak) SKSI, 2010.

[6] Bilčík J., Fillo L., Benko V., Halvoník J. Concrete structures, Design according to STN EN 1992-1-1, (in Slovak) Slovak University of Technology in Bratislava, 2008.

[7] Paulík P., Bačuvčík M., Ševčík P., Janotka I., Gajdošová K. Experimental evaluation of properties of 120 years old concretes at two concrete bridges in Slovakia, Solid State Phenomena, Vol. 249, 2016, pp. 227-234.

[8] Cavojcová A., Moravčík M. Fatigue assessment of concrete members strengthened by FRP materials, Journal Applied Mechanics and Materials, Vol. 617, 2014, pp. 221-224.

[9] Holý I., Bilčík J. Experimental and numerical analysis of corrosion in RC structures on bond behavior, International Masaryk Conference for PhD Students and Young Scientists, Hradec Kralove, Czech republic, 15-19 December 2014, p. 4015-4022.

[10] Benko V., Kišac M., Kendický P., Strauss A., Šalát T., Lašán L. Predicting the resistance of thin concrete columns to stabilized failure, Expert magazine 'Concrete-technology, construction, redevelopment', Vol. 14, No. 1, 2014, pp. 75-79.

[11] Kala V., Valeš J. Stochastic analysis of the lateral beam buckling of beams with initial imperfections, Proceedings of the 25th European Safety and Reliability Conference on 
Safety and Reliability of Complex Engineered Systems, ESREL 2015, Zurich, Switzerland, 07-10 September 2015, pp. 2547-2552.

[12] Krejsa M., Koubova L., Flodr J., Protivinsky J., Nguyen, Q. T. Probabilistic prediction of fatigue damage based on linear fracture mechanics, Fratturaed Integrita Strutturale, Vol. 11, No. 39, 2017, pp. 143-159.

[13] Krejsa M. Probabilistic reliability assessment of steel structures exposed to fatigue, Proceedings of the European Safety and Reliability Conference on Safety, Reliability and Risk Analysis: Beyond the Horizon, ESREL 2013, Amsterdam, The Netherlands, 29 September-2 October 2013, pp. 2671-2679.

[14] Macho M., Ryjaček P. The impact of the severe corrosion on the structural behavior of steel bridge members, Proceedings of the International Conference on Engineering Sciences and Technologies, ESaT 2015, Tatranská Štrba, High Tatras Mountains, Slovak Republic, 27-29 May 2015, pp. 123-128.

[15] Ryjaček P., Macho M., Stančík V., Polák M. The deterioration and assessment of steel bridges, Proceedings of the 8th International Conference on Bridge Maintenance, Safety and Management, IABMAS 2016, Foz do Iguaçu, Brazil, 26-30 June 2016, pp. 1188-1195.

[16] Lantsoght E. O. L., van der Veen C., de Boer A., Hordijk D. A. Proof load testing of reinforced concrete slab bridges in the Netherlands, Structural Concrete, Vol. 18, 2017, pp. 597-606.

[17] Faber M. H., Val D. V., Stewart M. G. Proof load testing for bridge assessment and upgrading, Engineering Structures, Vol. 22, No. 12, 2000, pp. 1677-1689.

[18] Koris K., Bódi I. Service life estimation of pre-cast concrete structural members, Pollack Periodica, Vol. 4, No. 1, 2009, pp. 63-74.

[19] Gabor R., Petzek E., Bancila R. Criteria for optimization of motorway crossings in steel concrete bridges, Pollack Periodica, Vol. 2, No. 3, 2007, pp. 45-56.

[20] STN 73 6209: Loading tests for bridges, (in Slovak) Slovak Office of Standards, Metrology and Testing, 1987.

[21] STN EN 1991-2 (73 6203): Eurocode 1, Actions on structures, Part 2, Traffic loads on bridges, (in Slovak) Slovak Office of Standards, Metrology and Testing, 2006.

[22] STN 73 6206: Design of concrete and reinforced concrete bridge structures, (in Slovak) Slovak Office of Standards, Metrology and Testing, 1989.

[23] STN 73 6203: Action on bridges, (in Slovak) Slovak Office of Standards, Metrology and Testing, 1988. 